\title{
Helping to Plan a Boundaryless Career: Notes on the Role of Counselling in Promoting Professional Mobility
}

\author{
Violetta Drabik-Podgórna
}

University of Wroclaw, Department of Historical and Pedagogical Sciences, Institute of Pedagogy, ul. J. W. Dawida 1, 50-527 Wrocław, Poland, violettapodgorna@gmail.com

\begin{abstract}
The article presents counselling as an activity that supports socialisation processes Lifelong career counselling helps young people prepare for vocational and life-related roles and aims to assist an individual in developing competencies one needs to function effectively on the labour market. One of such competencies is professional mobility, which is a typical marker of contemporary biographies called boundaryless career.
\end{abstract}

Keywords: boundaryless career, career counselling, professional mobility, socialization.

\section{Introduction}

The labour market is by no means homogeneous. As the segmentation conception holds, there are in fact several parallel markets. First of all, the primary and the secondary segments can be differentiated. The former means interesting jobs and rewarding pays. Jobs available on this market can be taken both by degree-holders (e.g. managerial positions in many companies) as well as by people with elementary or technical education (e.g. construction workers). The latter means poorly paid jobs, difficult working conditions, so-called “junk contracts” or enforced part-time employment (Guichard \& Huteau, 2005).

The competence model is becoming dominant in work organisation, with employers prioritizing the skills the candidate for a job actually has rather than a degree or a certificate in this or that vocation. And, irrespective of where on the labour market the employee winds up, the skills are supposed to include not only specialist occupational 
qualifications, but also - crucially, perhaps - interactive skills useful in work environments, e.g. communication competence, openness, ability to face up to unexpected situations, adaptability, flexibility, readiness for change and mobility (Guichard \& Huteau, 2005).

All this, obviously, alters the demands placed on education both as the site of socialisation and as a preparation for adult vocational life. Consequently, counselling services supposed to support the relevant educational processes are pressed to cater to different needs. It is becoming increasingly clear that the methods and strategies that educators and counsellors have been applying so far fail to meet the requirements generated by the contemporary world. Given the globalizing processes, new developments in technology, flexibility of working hours, and changes in the labour-related legislation (Beck, 2004) it does not suffice to equip graduates with vocational competencies. It is also urgent to prepare them for facing up to the realities of vocational chaos, which compel them to change jobs, acquire and improve professional skills and develop the ability to transfer from one sphere to another.

\section{Boundaryless career as a viable career model}

Not so long ago, vocation was a basic category that organised individual identity. Years of vocational education and training guaranteed finding a job and retaining it until retirement, and the vocation itself had an impact on the person's social status and prestige. To say now that a vocation cannot be chosen for a lifetime and a university degree does not launch one safely onto the labour market is but to repeat a trite platitude. Re-qualifying is a bare necessity, a task and a challenge. Vocations keep disappearing, while other ones are emerging in their place. On the whole, diversification of vocational activities has advanced so far that it makes less and less sense to speak in terms of vocations now. That is why the notion of vocation is growingly being replaced with the notion of career, even though "career" may evoke rather ambivalent responses. On the one hand, when we say in Poland that somebody "has made a career", we mean that they have been successful and / or promoted. On the other hand, however, the expression conjures up an uneasy sense of their obscure intentions and unsavoury connections. Some of the Polish derivatives of "career" have unambiguously pejorative connotations: for example, karierowicz (a careerist), as defined in Słownik Jezyka Polskiego [The Polish Language Dictionary], is an individual with no personal integrity, unscrupulous, opportunistic, a chameleon going with the tide; and karierowiczostwo (careerism) is an attitude to life in which success is to be achieved at any cost (Szymczak, 1978).

However, both the English career and the French carriere mean not only promotion and success, but also the entirety of professional path: a course of one's vocational life, which can and should be planned (Brzezińska\&Paszkowska-Rogacz, 2000). Such ideas 
inform various career-related educational programmes (career education, education du carriere) and underpin operations of vocational guidance services that currently tend to be re-named as career guidance or career counselling.

D. Super - a vocational guidance researcher - claims that career is a an inventory of events that make up life, a sequence of vocations and other life roles which, taken together, express a person's attitude to work as an aspect of his / her personality development; this is a list of paid or unpaid position the person takes up from puberty to retirement, with the job(s) being only one of them. Career includes work-related roles, such as a student, an employee, or a pensioner and also non-vocational, familial and civic roles (Super, 1994). In other words, career comprises not only a particular position one holds as an employee or the vocational path one has walked but also other functions inscribed in one's living space.

A. Bańka observes that career may have objective and subjective dimensions. The formeris bound up with career as a structural property of a vocation or an organisation. It is then understood as the vocational development path or as climbing up the ladder of the organisation's structures. It is, to quote A. Bańka, "the vector of mobility within an organisation" (Bańka, 2007). In subjective terms, career is a property of an individual and denotes "a sequence of employment-related positions, roles, activities and experiences the individual has acquired throughout his / her lifetime" (Bańka, 2007). In this sense what counts is primarily the inner sense of satisfaction and fulfilment and not only the objective achievements.

In the conditions of post-modernity, career development cannot be fully predicted and, hence, career tends to be perceived as a mosaic of life episodes (Wojtasik, 2003). The episodes are single projects of tasks to be performed in various spheres of activity. According to Z. Bauman, the sequence in which the projects are realised is by no means predetermined and, largely, it tends to be random. Each subsequent project is by definition a new one, it differs from the previous projects, and it demands new competencies and creative solutions (Bauman, 2001). Therefore, new career models and new biographic patterns are coming into being.

Discussing career in the $21^{\text {st }}$ century, J. Biolos distinguishes five career models. They are: an expert, a traditionalist, a planful entrepreneur, a spontaneous entrepreneur and a portfolio manager (Biolos, 2006). The expert seeks to accumulated specialist knowledge, focuses on development and improvement in a particular sphere, but does not necessarily stick to one workplace. The organisation is, in turn, important to the traditionalist, who gradually advancing heads toward still higher positions to finally attain power (vertical career). The planful entrepreneur works is a medium-sized or big organisation for some time, gathers experience, watches how others do things, and develops his / her own skills in order to use all these resources to set up his / her own company. Having collected the necessary competencies, $s$ / he simply leaves the organization. The spontaneous entrepreneur does not have any specific designs connected with the organisation s / he works in. 
However, as soon as $\mathrm{s} / \mathrm{he}$ discovers some kind of passion or spots a once-in-a-lifetime opportunity, s / he is ready to abandon all the rewards that the organisation offers in order to put his / her ideas into practice. In the context of this article, the last career model distinguished by J. Biolos seems to be the most interesting. The portfolio manager works in different companies, „travels” and compiles professional experience, achievements, and new skills conducive to combining professional success and personal independence. $S$ / he prioritizes tasks which foster personal development, creativity and autonomous decision-making (Biolos, 2006). S / he keeps acquiring knowledge and changing jobs, creating in this way his / her own vocational portfolio of growing expertise and skills.

Similar changes in the course of career are noted by M. Domecka and A. Mrozowicki, who on the basis of workers' and businessmen's vocational careers in Poland after the socio-political shift of 1989, distinguished three career models: an anchor, a patchwork and a construction (Domecka \& Mrozowicki, 2008). The anchor career type denotes being employed in one company from graduation to retirement. It is marked by an effort to preserve the status quo: practices, action strategies, habits that one has developed, jobs and positions. Usually, it takes place within a one company or within one branch of industry since it is closely bound up with a particular vocation. Actually, as M. Domecka and A. Morozowski write, the vocational competencies one requires can be improved and redefined, but they cannot be abandoned for the sake of a completely new set of skills (Domecka \& Mrozowicki, 2008).

The patchwork career model comprises various, often inconsistent and divergent kinds of vocational experience. This career model does not result from a personal plan or a conscious choice, but is a consequence of occupational chaos and difficulties one experiences and tries to cope with in a variety of ways. Career is constructed depending on particular circumstances and "includes externally enforced workplace changes or parallel engagement in diverse vocational activities which do not involve similar skills as they may be part of separate branches in which one works" (Domecka \& Mrozowicki, 2008).

The last career model the authors distinguish is a construction. Similarly to the patchwork, an individual's vocational identity is built on the basis of diverse experiences. However, in this case the activities one engages in are purposefully selected. Construction entails consciously planned, designed and actually executed decisions and (often innovative, but also risky) undertakings aiming to expand the resources one possesses and use them to transform one's vocational position and situation in life. "Such career model consists of a series of vertical and horizontal moves within one or a few organizations, as well as meaningful turning points, which re-direct the career path, accelerate it, prompt it and open up opportunities of professional development" (Domecka\&Mrozowicki, 2008).

The model of boundaryless career emerges in this context of mutating career patterns and biographical paths. Boundaryless career contains elements of career described in the aforementioned portfolio manager, patchwork and construction models. Boundaryless career means first of all a career "that is not clearly divided among vocations and jobs, 
public and family spheres, production and service sectors, specialist and non-specialist activities" (Bańka, 2006). Boundaryless career entails working for more than one employer, beyond one's own company, sometimes across the border of the town, province or the county. It means also (or perhaps first of all) constructing a career as a conscious project of social mobility. Considering the changes that are taking place in the arrangement and mechanisms of modern organisations in which hierarchical structures are flattened and promotion is basically impossible, we should notice that career may have only the horizontal dimension (i.e. development and expansion of competencies). Reflecting on M. B. Arthur's and D. M. Rousseau's observations, M. Rutkowska realises that boundarysless career means also "an individual's subjective interpretation of his / her career, which can be viewed in terms of "boundarylessness" even if $s$ / he is in fact naturally constrained (Rutkowska, 2010).

Boundaryless career is related to the so-called Proteancareer, which is typical of those who endorse independence in building their career, resorting to individual values which make up the criterion for assessing their achievements. Managing a career entails in this model adapting to the environment's requirements and openness to new experience (Rutkowska, 2010).

\section{Mobility in the contemporary boundaryless career}

The research conducted by the CBOS (Centre for Public Opinion Surveys) in 2013 showed that within the last five years almost $1 / 3$ of employed adult Poles (31\%) had at least once changed jobs. One in six employees (16\%) stated that they were going to change their jobs, wherein one in sixteen (6\%) wanted that as soon as possible. More than 1/5 of the employees $(22 \%)$ did not intend to look for a new job and a group nearly thrice as big (60\%) did not consider that at all. At the same time, if offered a better job, even if it required other qualifications than those the respondents possessed, as many as half of them (51\%) would be inclined to take it and one in five $(21 \%)$ would not hesitate in the least about it. However, despite their declared openness to change, as many as three fourths of the working respondents stated that it would be difficult for them to find another job paid approximately the same as they earned. As compared to the research results obtained four years before, Poles' readiness to sacrifice has considerably increased, with their willingness to improve qualifications and learn a new vocation growing in particular (Boguszewski, 2013)

A. Bańka observes also the phenomenon of transmigration, which is not identical with emigration. He writes that "on the one hand, we have the category of tourists, festival goers, international students and other transcultural travellers, and on the other, we have truck drivers in international transportation and shipment companies and sailors" (Bańka, 2006). The group of those who take up jobs abroad includes, among others business 
travellers, commuting / extended visitors, labour tourists, temporary sojourners, flexible contracted employees calledalso nomadic workers and qualified migrants targeting permanent relocation. Additionally, A. Bańka enumerates non-typical employees, such as working holidaymakers, overseas assigners, sojourners and international students (Bańka, 2006).

Nevertheless, as mentioned above, boundaryless career entails more than physical mobility and shifting in the geographically defined space. It crucially requires also certain mental predispositions and inner attitudes. Of course, opportunities of travelling across the world provide new chances of self-realisation and frequently release previously unavailable resources. Yet, the very fact of staying abroad does not necessarily mean using all the options offered by the foreign labour market. Moreover, taking up a job abroad is not always a free choice, but tends to be a necessity: in some cases earning a decent livelihood for the family who stay back home is hardly possible otherwise. This makes it necessary to possess or develop adaptability to new conditions, acceptance of otherness, tolerance for diversity and flexibility in adjusting to new environments. At the same time, mental mobility entails also resettling securely when one has already returned from abroad. All this means that boundaryless career relies on the so-called mobility capital, which denotes "an individual's total experience $<\ldots>$ that fosters creative and effective coping in new settings and new situations” (Bańka, 2006).

\section{Counselling as help in forming mobility}

Guidelines for career counselling practitioners formulated by European institutions emphasise that the goal of counselling and educational activities is to promote mobility. Lifelong learning is accompanied by lifelong counselling. The resolution of the European Council of Ministers of Education (2004) states that lifelong career counselling contributes to achievement of the EU goals in economic development, labour market effectiveness, and geographical and professional mobility by increasing effectiveness of investment in vocational education and training, lifelong learning, and human resources and labour force development. Globalization processes make European and worldwide labour market open, which entails the free flow of both financial capital and also human capital and career capital.

The specific tasks that career counselling is to perform today is largely bound up with the youth socialisation modes. In the second half of the $20^{\text {th }}$ century, educational systems still disseminated the model of a stable identity crystallized in a social and occupational role, which in practice meant learning a vocation and practising it up to retirement. The logic of vocational choices followed the school logic, that is, the students imagined their future vocational role in reference to their position in classroom, grades and interest in school subjects (Dumora, 1990). The transition from the student role to the employee role 
seemed to consist in a simple transfer of school-related competencies onto the vocational and life-related competencies.

This is, however, changing now. Although schools offer various vocational training options, the students' interests go beyond the subjects taught at school and young people's attention focuses on other forms of activity than those offered by educational facilities (It happens, for example, that already in lower secondary schools, the school websites are managed by the students and not by the network administrators employed by the schools, because the students' IT competencies exceed the set learning outcomes for IT inscribed in the elementary and secondary education curricula). Gradually, the decisions about projects for the future are based on the life-oriented logic, which means that aspirations and plans are connected with the realisation of a complex self-image (involving not only a vocational role, but also familial and civic roles). This requires forming an ability to move among various contexts and transfer competencies from one context to another.

Also, vocations have become just contexts in which various career paths are realised, and global markets increasingly demand physical mobility, which makes the socialization process take on different forms. As M. Wieviorka notices, "yesterday, socialisation was a process through which an individual - and first and foremost a child - was supposed to find his/her place in society, integrate with it, learn its codes and norms, and get adjusted to it. Today, socialization is predominantly a process in which an individual gains and develops skills of managing his / her experience and being the agent in his / her life" (Wieviorka, 2013).

It is essential insofar as the contemporary labour market cannot guarantee employment for all. As a result, paid employment is destandardised (e.g. work can be performed in various time arrangements, various forms employment except full-time jobs are possible, one can work in "a sky drive", i.e. in the cyberspace without a tangible workplace, etc.). In parallel, careers must be repeatedly interrupted, and new ways to resume or continue them must be devised.

Discussing tasks that education must engage with in the face of the shrinking labour market, T. Szkudlarek emphasises that it should prepare young people not only for success in corporations, but also for life without paid employment, e.g. for continuing without work contracts and for social self-organisation (Szkudlarek, 2005). This means emphasis on shaping change-oriented attitudes, initiative, mobility and an active take on challenges. The aims defined in this way are directly implicated in boundaryless career.

When career becomes "an integrative framework for the sense of identity throughout individual life-course" (Bańka, 2007), life-long counselling, which prepares young people for realising the boundaryless career model, becomes the process of assisting them in designing the path of development, in building inner resources and in assuming responsibility for their lives. It is help that aims to construct life scenarios promoting crossing borders, adapting to different environments, assimilating patterns that enhance mental mobility, showing possibilities of life and development in on-going change, supporting 
people in coping with negative effects of change, and fostering constant renewal of personal potentials (Bańka, 2007).

\section{Conclusion}

How to help in planning a boundaryless career? This question probes into the role of career counselling in shaping competencies that promote an individual's physical and mental mobility. To answer it, we must perceive the relations between the socializing processes which take place in educational facilities and the changing patterns of people's vocational biographies. If an individual's life-course is marked with permanent changes and careers become dynamic systems of experience which shape the self-image, lifelong education cannot be reduced to training in narrow specialisations. Rather, it should teach how to construct identities self-reflectively, how to acquire competencies necessary to cope with the unpredictable, and how to build an open personality ready to transform the inner career capital resources.

\section{References}

Bańka, A. (2006). Poradnictwo transnacjonalne. Cele i metody międzykulturowego doradztwa karier MPiPS (pp. 11, 10, 18-19, 19-20, 23-24). Warszawa: Departament rynku pracy.

Bańka, A. (2007). Psychologiczne doradztwo karier (p. 25). Poznań: PRINT-B.

Bauman, Z. (2001). Wieczność w opałach, czyli o wyzwaniach pedagogicznych płynnej nowoczesności. Teraźniejszość-Człowiek-Edukacja, Special Issue 2001.

Beck, U. (2004). Społeczeństwo ryzyka (pp. 210-213). Warszawa: Scholar.

Biolos, J., Brown, T., \& Saunders, R. M. (Eds.) Zarządzanie kariera (pp. 32-37). Warszawa: Wydawnictwo Studio Emka.

Boguszewski R., Komunikat z badań CBOS. Mobilność i elastyczność zawodowa Polaków, Warszawa, January 2013, [retrieved 29.09.2013]: http://www.cbos.pl/SPISKOM.POL/2013/K_011_13.PDF.

Brzezińska, E., \& Paszkowska-Rogacz, A. (2000). Kształtowanie relacji pracowniczych (p. 77). Łódź: PACZ.

Domecka, M., \& Mrozowicki, A. (2008). Robotnicy i ludzie biznesu. Wzory karier zawodowych a zmiana społeczna w Polsce. Przegląd Socjologii Jakościowej, IV, No 1 / 2008, 140, 144, 147.

Dumora, B. (1990). La dynamique wvocationnelle chez l'adolescentde college: continuite et rupture. L'Orientation Scolaire et Professionnelle, 19 / 1990, 11-127.

Guichard, J., \& Huteau, M. (2005). Psychologia orientacjii poradnictwa zawodowego (pp. 13, 14). Kraków: Impuls.

Rutkowska, M. (2010). Nowa kariera i jej egzemplifikacje w postaci kariery proteuszowej i kariery bez granic. Zarządzanie Zasobami Ludzkimi, 1 (72), 12. 
Super, D. (1994). Poradnictwo zawodowe - zajęcie wszechstronne (p. 162). Warszawa: Krajowy Urząd Pracy.

Szkudlarek, T. (2005). Koniecpracy' czykonie czatrudnienia? Edukacja wobec presji światowego rynku. In A. Kargulowa, P. Kwiatkowski, \& Szkudlarek T. (Eds.). Rynek i kultura neoliberalna a edukacja (pp. 13-32). Kraków: Implus.

Szymczak, M. (1978). Słownik Języka Polskiego, Vol. I (p. 886). Warszawa: PWN.

Wieviorka M., Grand résumé de Neufleçons de sociologie, Sociologies, retrieved 1.10.2013 http:// sociologies.revues.org/3367

Wojtasik, B. (2003) Refleksyjnekonstruowaniekarieryżyciowej w ponowoczesnejcodzienności, Teraźniejszość-Człowiek-Edukacja, Special Issue, 343 - 352.

\title{
I pagalbą planuojant plataus spektro karjerą: konsultavimo vaidmuo skatinant profesinị mobilumą
}

\author{
Violetta Drabik-Podgórna
}

Vroclavo universitetas, Istorijos ir pedagogikos katedra, Pedagogikos institutas,

J. W. Dawida g. 1, 50-527 Vroclavas, Lenkija, violettapodgorna@gmail.com

\section{Santrauka}

Straipsnyje nagrinejjamas karjeros konsultavimas kaip socializacijos procesus skatinanti veikla. Šiuolaikinè darbo rinka neužtikrina visų įdarbinimo, o i̇vairios darbo vietos virto plataus karjeros realizavimo kontekstu. Tai reiškia, kad kinta socializacijos procesas. Ugdymo sistema turètų rengti jaunus žmones ne tik sèkmingai veikti įmonėse, bet ir gyventi be pastoviai apmokamo darbo. $\mathrm{O}$ tai reikalauja kryptingai formuoti pokyčiams palankias nuostatas, asmens iniciatyvumą, mobilumą ir aktyvų nusiteikimą sutikti iššūkius. Šitaip suformuluoti tikslai atitinka plataus spektro karjeros pobūdį. Karjeros konsultavimas, plečiantis tokị ugdymą, siekia kurti pokyčiams pasirengusią asmenybę, gebančią keistis, pasitelkiant vidinius karjeros galimybių išteklius.

Esminiai žodžiai: plataus spektro karjera, karjeros konsultavimas, profesinis mobilumas, socializacija. 